\title{
Можливості ультразвукового дослідження у визначенні ехосеміотики раку голосового апарату
}

\author{
Т.М. Козаренко', І.О. Чемеркіна², Д.А. Кравченко ${ }^{3}$ Ю.О. Сережко \\ 'Національний університет охорони здоров'я імені П.Л. Шупика, Київ, Україна \\ Державна установа «Інститут отоларингології ім. проф. О.С. Коломійченка НАМН України», Київ, Україна \\ ${ }^{3}$ Центральний госпіталь м. Віндхук, Намібія
}

Анотація. Обстежено 305 хворих на рак голосового апарату I-III стадії ( $\left.\mathrm{T}_{1-3} \mathrm{~N}_{0} \mathrm{M}_{0}\right)$. Морфологічно в усіх випадках виявлено зроговілий та незроговілий плоскоклітинний рак. Оцінку даних сонографії гортані проводили за допомогою відеоендоскопії та під час оперативного втручання. Створено перелік ознак раку середнього відділу гортані при ультразвуковому дослідженні. Всі ознаки раку голосового апарату, що визначаються при ультразвуковому дослідженні, дають можливість оцінити локалізацію та деякою мірою стадію пухлинного ураження. Визначена ефективність сонографії при раку голосового апарату. Чутливість ультразвукового дослідження гортані становила 84,4\%, точність $-77,1 \%$.

Ключові слова: рак, голосовий апарат, ультразвукове дослідження.

\section{Вступ}

Найбільш поширеним захворюванням серед злоякісних пухлин верхніх дихальних шляхів $\epsilon$ рак гортані, питома вага якого у загальній кількості онкологічних захворювань становить 4,1-4,8 на 100 тис. населення, а в структурі ЛОР-онкозахворювань близько 50\%. Місцево-поширені форми $\left(\mathrm{T}_{3-4}\right)$ діагностують у 57$70 \%$ випадків серед уперше виявлених. Незважаючи на відносну доступність діагностики раку гортані, лише в 30-40\% випадків виявляють обмежені пухлинні ураження $\left(\mathrm{T}_{1-2}\right)[1,2]$. Значна частка занедбаних стадій у первинних хворих негативно впливає на результати лікування як в Україні, так і в інших країнах [3].

Поліпшення результатів лікування може бути досягнуто лише за умови підвищення рівня своєчасної діагностики злоякісних новоутворень. Збільшення частки виявлення раку гортані на початкових стадіях пропорційно підвищить показник кращих результатів лікування. Відомо, що 5-річне виживання хворих при I стадії становить 90-95\%, при II - 50-90\% [3, 4].

При раку гортані найчастіше (у 69,8\%) уражується голосова складка [3]. Виявлення хворих на рак гортані лише цієї локалізації вже збільшить частку ранньої діагностики даної патології.

Існуючі методи діагностики раку гортані включають аналіз скарг хворого, пальпацію шиї, ларингоскопію з біопсією, фіброларингоскопію, рентгенівську томографію гортані, ультразвукове дослідження (УЗД) шиї, комп'ютерну томографію, магнітно-резонансну томографію, позитронно-емісійну томографію та морфологічне дослідження пухлини. Одним із перспективних методів дослідження при раку голосового апарату може бути УзД гортані. Метод УЗД головним чином застосовують для візуалізації зони та ступеня ураження лімфатичних вузлів шиї, а також можливе його застосування при дослідженні гортані [4-6]. УЗД гортані запропоноване ще у 1990 р. [4]. Цей метод дослідження вважається інформативним при пухлинному ураженні середнього відділу гортані. Перевагами УзД $\epsilon$ неіонізуюче випромінювання, проведення процедури у режимі реального часу, високе просторове розділення, портативність методу, можливість багаторазового застосування в одного хворого та проведення інтервенційної процедури під час сканування. Недоліками УЗД $\epsilon$ вузьке поле огляду, залежність якості зображення рухомих частин гортані від осифікації щитоподібного хряща та утруднення дослідження у хворих з трахеостомою [7-10]. Порівняно 3 комп'ютерною томографією при УЗД м'яких тканин шиї та гортані якість зображення $€$ значно гіршою [6].

При огляді можна оцінити рухомість та симетричність рухів голосових складок, черпалоподібних хрящів, визначити розміри та межі повітряного стовпа гортані $[4,6,10,11]$. При великих розмірах пухлин переважно гетерогенної структури в них можуть визнача- ти гіпоехогенні ділянки (порожнини) за рахунок розпаду тканини пухлини. Таким чином, втрачається можливість диференціювання окремих структур гортані, які охоплені пухлиною. За даними Л.Г. Кожанова та співавторів (2009), в усіх хворих з ендофітною формою раку виявлено інфільтрацію м'яких тканин шиї, яка у 37,2\% хворих поєднувалася з деструкцією пластинок щитоподібного хряща, а у $33,3 \%$ випадків виявлено потовщення стінок грушовидного синусу за рахунок поширення пухлини гортані у глотку [9]. Також визначено ураження щитоподібної залози у $21,5 \%$ випадків. Разом із тим до цього часу неповною мірою розроблені чіткі ультразвукові критерії при раку голосового апарату.

Мета - підвищити інформативність УзД для удосконалення визначення ехосеміотики раку голосового апарату.

\section{Об'єкт і методи дослідження}

У ДУ «Інститут отоларингології ім. проф. О.С. Коломійченка НАМН України» проведено УЗД гортані 305 хворих на рак голосового апарату (чоловіки віком 43-75 років, середній вік 59 років). 3 І стадією раку голосового апарату виявлено 104 особи, з ІІ - 122 та з III - 79 осіб. Морфологічно в усіх випадках відмічали зроговілий та незроговілий плоскоклітинний рак. Для визначення нормальної сонографічної семіотики середнього відділу гортані обстежено 10 осіб з негортанною патологією.

УзД гортані проводили на ультразвуковому апараті «Sonoline G50» («Siemens») з використанням датчика частотою 7 МГц в режимі сірої шкали (В-режим) та допплерографії (енергетичний або кольоровий). Обстеження проводили у горизонтальному положенні хворого (на спині). УЗД гортані здійснювали шляхом сканування шиї від рівня (проєкції) під'язикової кістки до рівня яремної вирізки у фронтальній та фронтолатеральній площині. При цьому датчик утримували під кутом, який змінюється з урахуванням дихальних рухів гортані. Отримати чітке зображення рухомих ділянок гортані дозволяла мінімальна зміна кута нахилу датчика навколо своєї осі. Під час дослідження застосовували функціональну пробу з фонацією голосної літери «і», яку проводили у режимі нативного УзД (в режимі сірої шкали, В-режимі) та при допплерівському режимі. У нативному режимі визначали форму, наявність новоутворень, обмеження рухливості голосових складок, стан передньої та задньої комісури. У режимі допплерографії визначали зміни проходження повітря через серединний відділ гортані при фонації (для визначення рухливості складок та ступеня стенозу).

Оцінку даних сонографії проводили за допомогою відеоендоскопії гортані та під час оперативного втручання. Відеоендоларингоскопію гортані проводили гнучким відеобронхоскопом «EVIS Lucera AFI BF-F260». 


\section{Результати та їх обговорення}

За відсутності патологічних змін структура середнього відділу гортані має свої особливості. Щитоподібний хрящ виглядає ехопозитивною структурою лінійної форми товщиною 1-3 мм (рис. 1). Голосові складки візуалізуються як подовжні структури зниженої ехогенності. Просвіт гортані - анехогенний, обмежений з обох боків голосовими складками. Черпалоподібні хрящі визначаються у задніх відділах гортані і розташовані перпендикулярно до голосових складок. Вони мають лінійну форму та підвищену ехогенність. При фонації відмічали коливально-обертальний рух черпалоподібних хрящів.

При УзД гортані у 253 (83\%) хворих візуалізували екзофітну, у 52 (17\%) - ендофітну або змішану форму росту пухлини. За наявності пухлини гортані з екзофітною формою росту при сонографії відмічали нерівність контуру голосового апарату та звуження просвіту гортані. Для ендофітних пухлин характерно значне потовщення ураженого голосового апарату, внутрішнього охрястя та девіація пластинки щитоподібного хряща у 28 (9\%) хворих (рис. 2).

Дослідження гортані за допомогою УзД допомагає візуалізувати пухлини передньої комісури та передньої $1 / 3$ голосового апарату, ділянки черпалоподібних хрящів (рис. 3а-б), а іноді пухлин задньої комісури. Однак окостеніння пластинки щитоподібного хряща, яке визначали у 52 (17\%) хворих, значно погіршило візуалізацію гортані і діагностику пухлинного ураження ії середнього відділу.

У режимі допплерографії проходження повітря через голосову щілину окреслює її контури. Екзофітна частина пухлини голосового апарату, що виступає у просвіт гортані, краще візуалізується (рис. 4).

Рисунок 1 Сонограма, В-режим, аксіальне сканування: 1 - голосовий апарат, 2 - передня комісура, 3 - черпалоподібний хрящ, 4 - просвіт середнього відділу гортані, 5 - пластинка щитоподібного хряща
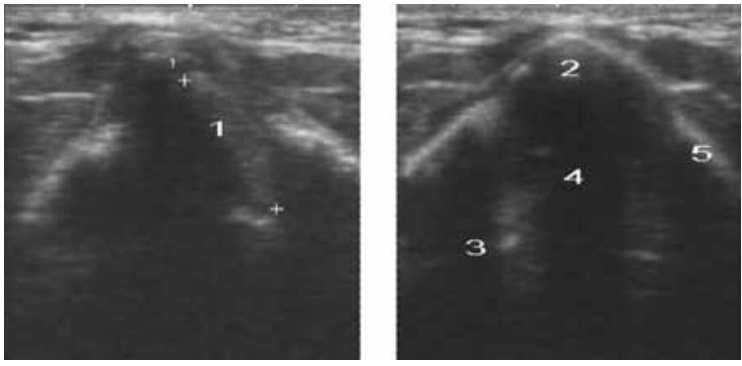

Рисунок 2 Сонограми гортані хворого С. В-режим, аксіальне сканування. Пухлина передньої $1 / 3$ лівої голосової складки. Девіація пластинки щитоподібного хряща

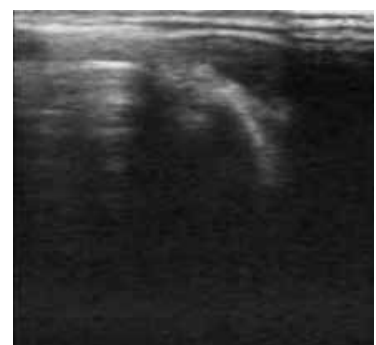

Рисунок 3 Ендоларингоскопія та сонограми $(a, 6)$ гортані хворого C. В-режим, аксіальне сканування: $a$ - пухлина всієї правої голосової складки, що прилягає до черпалоподібного хряща; 6 - поширення пухлини на передню комісуру та передню $1 / 3$ лівої голосової складки
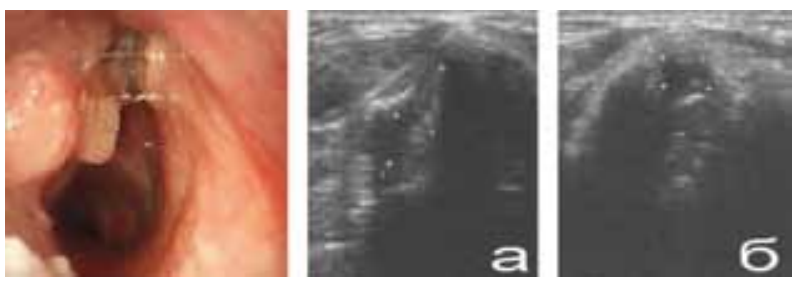

При фонації літери «і» діагностували обмеження рухливості голосового апарату у 122 (40\%) осіб, відсутність рухів ураженої половини гортані - у 79 (26\%) хворих.

Застосування режиму допплерографії під час фонаторної проби доповнило візуалізацію середнього відділу гортані новими ознаками пухлинного ураження голосового апарату. При однобічному пухлинному ураженні середнього відділу гортані, особливо при фіксованій голосовій складці (рис. 5), відбувається значне порушення їі рухливості. В умовах фонації голосної літери «і» протилежна неушкоджена голосова складка наближається до середньої лінії голосової щілини. Однак уражений пухлиною і обмежений в русі голосовий апарат не перекриває повністю голосової щілини. Спостерігається відхилення повітряного току у бік ушкодженого голосового апарату (рис. 6). Задокументоване зображення на сонограмі вказує на обмеження в русі або фіксацію голосового апарату, які визначаються при УзД гортані в реальному часі. У процесі дослідження гортані при сонографії візуалізували обмеження руху у 122 (40\%) та повну фіксацію голосового апарату у 79 (26\%) хворих.

При проведенні УзД визначені характерні ознаки раку середнього відділу гортані (таблиця). Рак голосового апарату має нечіткі (97\%) бугристі (51\%) контури, що деформують просвіт гортані. Пухлини у 71\% випадків середньої, у 29\% - зниженої ехогенності. У $34 \%$ випадків відмічали повну рухомість голосового апарату, обмеження рухливості - у $40 \%$, нерухомість - у $26 \%$ випадків. Пухлинне ураження передньої комісури визначали лише у $11 \%$ випадків. При УзД гортані у більшості (97\%) випадків визначали чіткий контур щитоподібного хряща. У 28 (9\%) випадках відмічено девіацію пластинки щитоподібного хряща. Окостеніння щитоподібного хряща виявлено у 52

Рисунок 4 Ендоларингоскопія та сонограми $(a, 6)$ гортані хворого П. В-режим, аксіальне сканування: $a$ - пухлина передньої комісури та передньої $1 / 3$ правої голосової складки; 6 кольорова допплерографія, аксіальне сканування: обтікання пухлини током повітря у режимі допплерографії
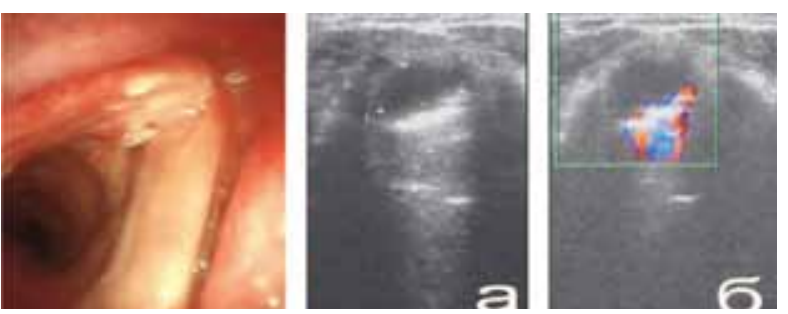

Рисунок 5 Ендоларингоскопія та сонограми $(a, 6)$ гортані хворого Т. В-режим, аксіальне сканування: $a$ - права голосова складка, ушкоджена екзофітною пухлиною; б - незмінена ліва голосова складка
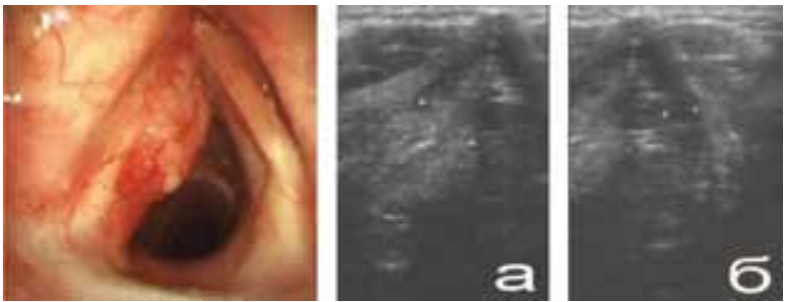

Рисунок 6 Сонограма гортані хворого Т. Кольорова допплерографія, аксіальне сканування. У режимі допплерографії відбувається відхилення току повітря у бік правої голосової складки, ушкодженої пухлиною

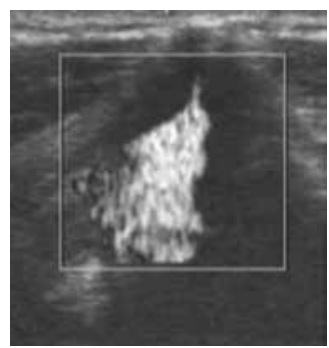


Таблиця Ознаки раку середнього відділу гортані при УЗД

\begin{tabular}{|c|c|c|c|c|c|c|}
\hline & \multirow{2}{*}{ Показник } & \multicolumn{5}{|c|}{ Кількість хворих } \\
\hline & & $\mathbf{n}$ & $\%$ & $\mathrm{~T}_{1} \mathrm{~N}_{0} \mathrm{M}_{0}$ & $\mathrm{~T}_{2} \mathrm{~N}_{0} \mathrm{M}_{0}$ & $\mathrm{~T}_{3} \mathrm{~N}_{0} \mathrm{M}_{0}$ \\
\hline & Всього випадків & 305 & 100 & 104 & 122 & 79 \\
\hline Ехоген- & Середня & 217 & 71 & 78 & 87 & 52 \\
\hline ність & Знижена & 89 & 29 & 26 & 35 & 25 \\
\hline Контури & Чіткі & - & - & - & - & - \\
\hline пухлини & Нечіткі & 296 & 97 & 104 & 113 & 79 \\
\hline & Рівні & - & - & - & - & - \\
\hline & Бугристі & 156 & 51 & 52 & 61 & 43 \\
\hline & Немає даних (окостеніння хряща) & 9 & 3 & - & 9 & - \\
\hline Щитопо- & Чіткий контур & 296 & 97 & 104 & 122 & 70 \\
\hline дібний & Нечіткий контур & 9 & 3 & - & - & 9 \\
\hline & Нерівний контур & - & - & - & - & - \\
\hline & Девіація хряща & 28 & 9 & - & 9 & 19 \\
\hline & Окостеніння хряща & 52 & 17 & 9 & 26 & 17 \\
\hline Просвіт & Деформований & 305 & 100 & 104 & 122 & 79 \\
\hline гортані & Не деформований & - & - & - & - & - \\
\hline Голосова & Рухома & 104 & 34 & 104 & - & - \\
\hline складка & 0бмежено рухома & 122 & 40 & - & 122 & - \\
\hline & Нерухома & 79 & 26 & - & - & 79 \\
\hline Передня & Уражена & 34 & 11 & 7 & 18 & 9 \\
\hline комісура & Вільна & 271 & 89 & 97 & 104 & 70 \\
\hline Пухлина & Правої & 162 & 53 & 52 & 68 & 42 \\
\hline голосової & Лівої & 125 & 41 & 47 & 45 & 33 \\
\hline складки & Обидві & 18 & 6 & 5 & 9 & 4 \\
\hline
\end{tabular}

(17\%) випадках, що у 9 випадках повністю утруднювало визначення контурів пухлини.

Хибнонегативні результати пов'язані з погіршенням візуалізації за рахунок окостеніння щитоподібного хряща гортані різного ступеня. Нерозпізнані поширення пухлини: на передню комісуру - у 9 (2,9\%), вестибулярну складку і шлуночок гортані - по 26 (8,6\%), підголосниковий відділ гортані - у 9 (2,9\%), пластинку щитоподібного хряща - у 17 (5,6\%) випадках. Помилкове, хибнопозитивне поширення пухлини виявлено в 17 випадках у передню комісуру та по 9 випадків у міжчерпакуватий простір та підголосниковий відділ. Чутливість та точність УЗД гортані становили 84,4 та 77,1\% відповідно.

\section{Висновки}

1. УзД гортані дозволяє визначити форму, наявність новоутворень та оцінити обмеження рухливості голосового апарату, стан передньої та задньої комісури, зміни в структурі щитоподібного хряща.

2. Використання режиму допплерографії та застосування функціональної проби при фонації голосної літери «і» покращують ультразвукову візуалізацію раку середнього відділу гортані.

3. Застосування встановленої патогномонічної ехосеміотики раку голосового апарату дозволило довести рівень чутливості та точності УзД до 84,4 та 77,1\% відповідно.

\section{Список використаної літератури}

1. Ukrainian Cancer Registry statistics (2020) Cancer in Ukraine, 2018-2019. Bulletin of the National cancer registry of Ukraine. Kyiv, $147 \mathrm{p}$.

2. Ukrainian Cancer Registry statistics (2021) Cancer in Ukraine, 2019-2020. Bulletin of the National cancer registry of Ukraine. Kyiv, $136 \mathrm{p}$.

3. Zhang S.-Y., Lu Zh.-M., Luo X.-N. et al. (2013) Retrospective analysis of prognostic factors in 205 patients with laryngeal squamous cell carcinoma who underwent surgical treatment. PLoS One, 8(4): e60157. doi: 10.1371/journal.pone.0060157

4. Абызов Р.А. (1990) Повышение эффективности диагностики илечения злокачественных новообразований верхних дыхательныхпутей. Автореф. дис..... д-ра мед. наук. Киевский НИИ отоларингології МЗ УССР. Киев, 40 С.

5. Евчев Ф.Д. (2008) Злокачественные опухоли гортани. Астропринт, Одесса, 328 с.

6. Козаренко Т.М., Дикан І.М., Логаніхіна К.Ю. (2011) Можливості комплексного ультразвукового дослідження в діагностиці метастатично уражених лімфатичних вузлів шиї у хворих на рак гортані. 36. мат. Наук.-практ. конф. «Новітні досягнення ранньої діагностики та лікування пухлин та пухлиноподібних утворень голови та шиї. Досвід. Проблеми. Шляхи вирішення», 20-21 травня, Черкаси.

7. Абизов Р.А. (2001) Онкооториноларингологія. Київ, Книга плюс, 272 c.

8. Козаренко Т.М. Кравченко Д.А., Сережко Ю.А. (2011) Функциональные пробы при сонографии срединного отдела гортани. IV Международный конгресс «Опухоли головы и шеи. Байкал-2011», 2-4 сентября, Иркутск.

9. К Кожанов Л.Г., Сдвижков А.М., Мулярец М.В. (2009) Возможности ультразвукового исследования гортани в диагностике рака. Онкохирургия, 1(2), с.18.

10. Козаренко Т.М. Кравченко Д.А., Сережко Ю.О., Логаніхіна К.Ю. (2011) Можливості ультразвукового дослідження гортані у хворих на рак серединного відділу гортані І-ІІ стадії. Щорічна традиційна весняна конф. Укр. наук. мед. тов-ва отоларингологів «Діагностика та лікування хронічних захворювань ЛОР-органів», 16-17 травня, Одеса.

11. Erkan V. Tolu I., Aslan T., Guney E. (1993) Ultrasonography in laryngeal cancers. J. Laryngol. Otol., 107: 65-68.

\section{Possibilities of ultrasonography in determining the echosemiotics of vocal cord cancer}

\section{T.M. Kozarenko', I.O. Chemerkina², D.A. Kravchenko³, Yu.O. Serezhko ${ }^{2}$}

'Shupyk National Healthcare University of Ukraine, Kyiv, Ukraine

${ }^{2} \mathrm{SI}$ «O.S. Kolomiychenko Institute of Otolaryngology

of NAMS of Ukraine», Kyiv, Ukraine

${ }^{3}$ Windhoek Central Hospital, Namibia

Abstract. 305 patients with vocal cord cancer stage I-III $\left(T_{1-3} N_{0} M_{0}\right)$ were examined. Morphologically, in all cases, keratinized and non-keratinized squamous cell carcinoma was detected. Evaluation of laryngeal sonography data was performed by video endoscopy of the larynx and during surgery. The list of signs of cancer of the middle larynx during the ultrasound examination was determined. All the signs of vocal cord cancer, which are determined by ultrasound, make it possible to assess the location and to some extent the stage of laryngeal tumor. The effectiveness of sonography in cancer of the vocal folds has been determined. The sensitivity of ultrasound of the larynx was $84.4 \%$ and the accuracy was $77.1 \%$.

Key words: cancer, vocal cord, ultrasound.

\section{Відомості про авторів:}

Козаренко Тетяна Маратівна — доктор медичних наук, професор кафедри променевої діагностики Національного університету охорони здоров'я імені П.Л. Шупика, Київ, Україна.

Чемеркіна Ірина Олександрівна — оториноларинголог, лікар ультразвукової діагностики, ДУ «lНститут отоларингології ім. проф. О.С. Коломійченка НАМН України», Київ, Україна.

Кравченко Діана Анатоліївна — кандидат медичних наук, оториноларинголог, Центральний госпіталь м. Віндхук, Намібія.

Сережко Юрій Олексійович — кандидат медичних наук, старший науковий співробітник відділу онкопатології ЛОР-органів ДУ «Інститут отоларингології ім. проф. О.С. Коломійченка НАМН України», Київ, Україна.

\section{Адреса для кореспонденції:}

Сережко Юрій Олексійович

03057, Київ, вул. Зоологічна, 3

E-mail:yualse2016@ukr.net
Information about the authors:

Kozarenko Tatiana M. - Doctor of Medical Sciences, Professor of the Department of radio diagnostics of the Shupyk National Healthcare University of Ukraine, Kyiv, Ukraine.

Chemerkina Iryna 0. — Otorhinolaryngologist, Ultrasound diagnostician, $\mathrm{Sl} « 0 . \mathrm{S}$. Kolomiychenko Institute of Otolaryngology of NAMS of Ukraine», Kyiv, Ukraine.

Kravchenko Diana A. — Candidate of Medical Sciences, Otorhinolaryngologist, Windhoek Central Hospital, Namibia.

Serezhko Yuriy 0. - Candidate of Medical Sciences, Senior researcher of the Department of oncopathology of the ENT organs of the $\mathrm{SI}$ « 0. S. Kolomiychenko Institute of Otolaryngology of NAMS of Ukraine», Kyiv, Ukraine.

Address for correspondence:

Yuriy Serezhko

03057, Kyiv, Zoological str., 3

E-mail:yualse2016@ukr.net 